Principles of International Auditing and Assurance 



\title{
Principles of International Auditing and Assurance
}

\author{
4th Edition
}

Rick Hayes, Philip Wallage and Peter Eimers 
Principles of International Auditing and Assurance, $4^{\text {th }}$ Edition, by Rick Hayes, Philip Wallage and Peter Eimers, is an extensively revised and updated edition of Principles of Auditing. An Introduction to

International Standaards on Auditing, 3 d Edition, by Rick Hayes, Philip Wallage and Hans Gortemaker (ISBN 9780273768173) published in 2014 with FT Prentice Hall, an imprint of Pearson Education.

Cover illustration: Mircea Costina / Adobe Stock

Cover design: Gijs Mathijs Ontwerpers, Amsterdam

Lay-out: Crius Group, Hulshout

$\begin{array}{ll}\text { ISBN } & 9789463720069 \\ \text { e-ISBN } & 9789048554164 \\ \text { DOI } & 10.5117 / 9789463720069 \\ \text { NUR } & 784\end{array}$

(C) R. Hayes, P. Wallage, P. Eimers / Amsterdam University Press B.V., Amsterdam 2021

All rights reserved. Without limiting the rights under copyright reserved above, no part of this book may be reproduced, stored in or introduced into a retrieval system, or transmitted, in any form or by any means (electronic, mechanical, photocopying, recording or otherwise) without the written permission of both the copyright owner and the author of the book. 


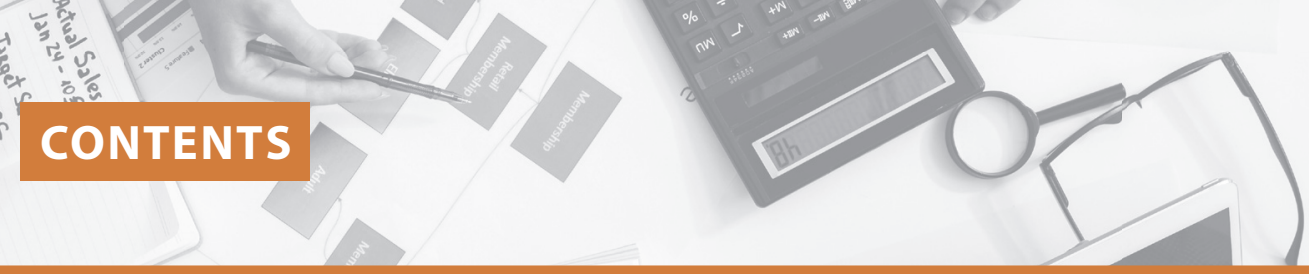

List of Illustrations

Foreword

Preface to the Fourth Edition

Acknowledgements

\section{SECTION I - HISTORY}

1.1 Learning Objectives

History

\section{SECTION II - THE PROFESSION}

2.1 Learning Objectives

2.3 Types of Auditor 


$\begin{array}{llr}2.10 & \text { Summary } & 83 \\ 2.11 & \text { Questions, Exercises and Cases } & 87 \\ 2.12 & \text { Notes } & 91\end{array}$

\section{SECTION III - ETHICS}

$\begin{array}{lll}3.1 & \text { Learning Objectives } & 94\end{array}$

$\begin{array}{lll}3.2 & \text { What Are Ethics? } & 94\end{array}$

3.3 The International Code of Ethics for Professional Accountants 97

3.4 Part 1 - Complying with the Code, Fundamental Principles and Conceptual $\begin{array}{lr}\text { Framework } & 99\end{array}$

3.5 Part 2-Professional Accountants in Business 106

3.6 Part 3 - Professional Accountants in Public Practice 108

3.7 Part 4-Independence Standards $\quad 115$

\begin{tabular}{ll}
3.8 & Enforcement of Ethical Requirements \\
\hline
\end{tabular}

$\begin{array}{llr}3.9 & \text { Summary } & 129\end{array}$

3.10 Questions, Exercises and Cases 132

$\begin{array}{llr}3.11 & \text { Notes } & 136\end{array}$

\section{SECTION IV — FUNDAMENTAL CONCEPTS}


5.1 Learning Objectives $\quad 152$

$5 \cdot 2 \quad$ Introduction 152

5.3 Responsibilities of the Board $\quad 155$

5.4 Auditor's Responsibility 155

$\begin{array}{llr}5.5 & \text { Fraud Defined } & 156\end{array}$

$\begin{array}{llr}5.6 & \text { Types of Fraud } & 158\end{array}$

$\begin{array}{llr}5 \cdot 7 & \text { Fraud Triangle and Anti-Fraud Measures } & 159\end{array}$

5.8 Audit Planning and Fraud Risk Assessment $\quad 162$

$\begin{array}{lll}5.9 & \text { Responses to Fraud Risk Assessment } & 167\end{array}$

5.10 Communication Related to Fraud with Management, Board and Third Parties 170

5.11 Compliance with Law and Regulation, Corruption and Money Laundering 172

$\begin{array}{ll}5.12 & 179\end{array}$

$\begin{array}{ll}5.13 & \text { Questions, Exercises and Cases } \\ 5.14\end{array}$

$\begin{array}{lll}5.14 & \text { Notes } & 186\end{array}$

\section{SECTION V - THE 4 PHASES OF EACH AUDIT ('HOW TO PERFORM AN AUDIT')}

\section{6 \\ Phase 1: Client and Engagement Acceptance / Continuance

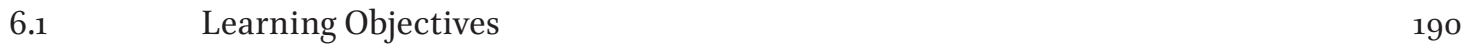

6.2 Client Acceptance and Continuance: The First Step on the Journey to an Opinion 191

6.3 Evaluate the Client's Background 192

$\begin{array}{ll}6.4 & 196\end{array}$

6.5 Ability to Meet Ethical and Specific Competence Requirements 209

6.6 Use of Other Professionals in the Audit 212

6.7 Communicating With the Predecessor (Existing) Auditor 216

6.8 Acceptance by the Client - The Engagement Proposal 217

6.9 The Audit Engagement Letter 221

$\begin{array}{ll}6.10 & \text { Summary } \\ 6.11 & 225\end{array}$

6.11 Questions, Exercises and Cases $\quad 228$

$6.12 \quad$ Notes 232

\section{$7 \quad$ Phase II, Part 1: Planning Through Understanding and Risk Analysis 236}

$\begin{array}{lll}7.1 & \text { Learning Objectives } & 236\end{array}$

$\begin{array}{lll}7.2 & \text { Planning Objective and Procedures } & 236\end{array}$

7.3 Understanding the Entity and its Environment 237 
7.4 Audit Risk Model 250

$\begin{array}{lll}7.5 & \text { Materiality } & 257\end{array}$

7.6 Fraud and Irregularities $\quad 262$

7.7 Using the Work of Others and Considering Auditee Use of Service Organizations 263

$\begin{array}{lll}7.8 & \text { Other Planning Activities } & 268\end{array}$

$\begin{array}{lll}7.9 & \text { Summary } & 270\end{array}$

$\begin{array}{ll}7.10 & \text { Questions, Exercises and Cases }\end{array}$

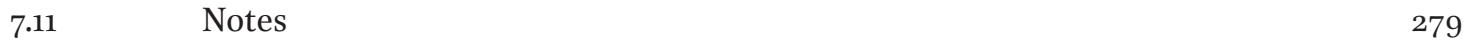

$8 \quad$ Phase II, Part 2: Internal Control and Control Risk 282

8.1 $\quad$ Learning Objectives 282

$\begin{array}{lll}8.2 & \text { Introduction } & 282\end{array}$

$\begin{array}{ll}8.3 & \text { Internal Control Defined }\end{array}$

$\begin{array}{lll}8.4 & \text { The Importance of Internal Control } & 285\end{array}$

$\begin{array}{lll}8.5 & \text { IT Risk and Controls } & 288\end{array}$

8.6 Components of Internal Control $\quad 291$

$\begin{array}{ll}8.7 & \text { Control Environment } \\ 8.8 & 292\end{array}$

$\begin{array}{lll}8.8 & \text { Risk Assessment } & 299\end{array}$

8.9 Information Systems, Communication and Related Business Processes 302

$\begin{array}{ll}8.10 & \text { Control Activities }\end{array}$

$\begin{array}{lll}8.11 & 310\end{array}$

8.12 Hard and Soft Control $\quad 311$

$\begin{array}{lll}8.13 & \text { Design of Internal Controls } & 314\end{array}$

$\begin{array}{lll}8.14 & \text { Preliminary Assessment of Control Risk } & 316\end{array}$

$\begin{array}{lll}8.15 & \text { Summary } & 317\end{array}$

8.16 Questions, Exercises and Cases $\quad 321$

$\begin{array}{lll}8.17 & \text { Notes } & 327\end{array}$

\section{$9 \quad$ Phase III, Part1: Building and Execution of the Test Plan and Auditor's}

Response to Assessed Risk 330

$\begin{array}{lll}9.1 & \text { Learning Objectives } & 330\end{array}$

$\begin{array}{lll}9.2 & \text { The Basis of Evidence } & 330\end{array}$

9.3 Financial Statement Assertions 333

9.4 Audit Procedures for Obtaining Audit Evidence 333

9.5 Sufficient Appropriate Audit Evidence 346

9.6 Tests of Controls 351

$\begin{array}{lll}9.7 & \text { Substantive Procedures } & 357\end{array}$

$\begin{array}{lll}9.8 & \text { Sampling } & 362\end{array}$

$\begin{array}{lll}9.9 & \text { Summary } & 367\end{array}$

9.10 Questions, Exercises and Cases 370

$\begin{array}{lll}9.11 & \text { Notes } & 382\end{array}$ 
10.1 Learning Objectives $\quad 385$

10.2 Analytical Procedures during Different Phases in the Audit Process 385

$\begin{array}{lll}10.3 & \text { The Analytical Review Process } & 387\end{array}$

$\begin{array}{lll}10.4 & \text { Formulating Expectations } & 390\end{array}$

10.5 General Types of Analytical Procedures 392

10.6 Analytical Procedures as Substantive Tests 395

10.7 Follow-Up in Case of Unexpected Deviations $\quad 398$

10.8 Evaluation of Misstatements Identified During the Audit (ISA 450) 399

$\begin{array}{lll}10.9 & \text { Summary } & 400\end{array}$

10.10 Questions, Exercises and Cases 402

$\begin{array}{lll}10.11 & \text { Notes } & 412\end{array}$

11 Phase IV, Part 1: Evaluation and Completion 414

$\begin{array}{ll}\text { 11.1 } & \text { Learning Objectives }\end{array}$

$\begin{array}{lll}11.2 & \text { Introduction } & 414\end{array}$

11.3 Specific Considerations Gathering Evidence for Selected Items 415

$\begin{array}{lll}11.4 & \text { Written Representations } & 418\end{array}$

11.5 Review for Contingent Liabilities and Commitments 423

11.6 Review for Discovery of Subsequent Events 424

$\begin{array}{lll}11.7 & \text { Related Parties } & 427\end{array}$

11.8 Evaluation of Going Concern Assumption 432

11.9 Review of Financial Statements and Other Information 434

$\begin{array}{ll}11.10 & 437\end{array}$

$\begin{array}{lll}11.11 & \text { Summary } & 444\end{array}$

$11.12 \quad$ Questions, Exercises and Cases 445

$\begin{array}{lll}11.13 & \text { Notes } & 453\end{array}$

$\begin{array}{lll}12.1 & 456\end{array}$

$\begin{array}{lll}12.2 & 45^{6}\end{array}$

12.3 Basic Elements of the Auditor's Report $\quad 460$

$12.4 \quad$ Key Audit Matters (KAMs) 474

12.5 Emphasis of Matter Paragraph 475

$\begin{array}{lll}12.6 & \text { Type of Audit Report } & 478\end{array}$

12.7 Opinion on Internal Controls over Financial Reporting 486

12.8 Communications with those Charged with Governance 488

$12.9 \quad$ Long-Form Audit Report 494

12.10 Management Letter 495 
12.11 General Meeting of Shareholders 496

$\begin{array}{lll}12.12 & \text { Summary } & 496\end{array}$

12.13 Questions, Exercises and Cases $\quad 500$

$\begin{array}{lll}12.14 & \text { Notes } & 509\end{array}$

\section{SECTION VI - SPECIFIC THEMES AND TOPICS}

$\begin{array}{llr}13 & \text { Specific Themes and Special Topics during The Audit } & 512 \\ 13.1 & \text { Learning Objectives } & 512 \\ 13.2 & \text { Quality Control (ISQC 1, ISA 220, SOX) } & 512 \\ 13.3 & \text { Technology in the Audit } & 516 \\ 13.4 & \text { Group Audit } & 519 \\ 13.5 & \text { Audit of Accounting Estimates (ISA 540) } & 530 \\ 13.6 & \text { Summary } & 533 \\ 13.7 & \text { Questions, Exercises and Cases } & 535 \\ 13.8 & \text { Notes } & 541\end{array}$

\section{A Group Audit Extended Example}

13A.1 Learning Objectives $\quad 544$

13A.2 Context of Extended Example of a Group Audit 545

13A.3 The Audit Planning Memorandum - Strategy Part $55^{\circ}$

13A.4 The Audit Planning Memorandum - Plan Part 555

13A.5 Audit Programme (Audit Plan) 559

13A.6 Completion Memorandum $\quad 576$

$\begin{array}{lll}13 \mathrm{~A} .7 & \text { Questions, Exercises and Cases } & 583\end{array}$

13A.8 Notes $\quad 592$

\section{SECTION VII — OTHER ASSURANCE AND RELATED SERVICES}

\section{Other Assurance and Related Services}

$\begin{array}{lll}\text { 14.1 } & \text { Learning Objectives } & 594\end{array}$

$\begin{array}{lll}14.2 & \text { The Concepts } & 594\end{array}$

$\begin{array}{lll}\text { 14.3 Elements of an Assurance Engagement } & 597\end{array}$

$\begin{array}{lll}14.4 & \text { Highlights of Various Kinds of Assurance Engagements } & 608\end{array}$

14.5 Assurance Engagements Other Than Audits or Reviews of Historical Financial Information 
CONTENTS

14.6

14.7

14.8

14.9
Related Services

Summary

Questions, Exercises and Cases

Notes
622

627

629

637

642

684

Glossary

Index 



\section{LIST OF ILLUSTRATIONS}

1.1 Theories Explaining Audit Supply and Demand 30

$1.2 \quad$ Overview of the Audit Process 36

1.3 The Result of Planning $\quad 38$

1.4 The COSO Report Objectives 43

2.1 Auditor Certification Designations Around the World 59

$\begin{array}{lll}2.2 & \text { Types of Audit } & 61\end{array}$

2.3 Big Four Organizational Pyramid $\quad 64$

$2.4 \quad$ Global Adoption of Clarified ISAs $\quad 72$

2.5 List of 2018 International Standards on Auditing $\quad 73$

$2.6 \quad$ Specific Country Oversight Boards $\quad 84$

3.1 Characteristics of Ethical Behavior $\quad 95$

3.2 Overview of the IESBA Code of Ethics $\quad 98$

3.3 Overview of Principles, Threats and Safeguards in the Code of Ethics 105

3.4 Part 2: Professional Accountants in Business 106

3.5 Independence in the Sarbanes-Oxley Act of $2002 \quad 116$

3.6 Part 4A Independence - Audit and Review Engagements 118

3.7 Part 4B: Independence - Other Assurance Engagements 127

3.8 Examples of Violations of Independence (Derived from SEC Press Releases) $\quad 128$

4.1 The Four Phases of the Audit 141

5.1 Fraud Detection Measures and Their Effect on the Duration of the Fraud and the Size of Loss (ACFE, 2018) 153

5.2 Synthesis of Fraud-Related Research (Trompeter et al, 2013). 157

5.3 Fraud Triangle $\quad 159$

5.4 What Anti-Fraud Measures Are Most Common? ACFE, 2018, Figure 17, p. $27 \quad 161$

5.5 How Is Occupational Fraud Initially Detected? (ACFE, 2018, p. 17, Figure 9) 163

5.6 KPMG's Independent Auditor's Report 2018 of Leaseplan Corporation NV $\quad 164$

5.7 Key Audit Matter Annual Report 2018 SBM Offshore NV $\quad 172$

5.8 Corruption Perception Index 2018, Transparency International 175

$\begin{array}{lll}5.9 & \text { External Auditors' Guide for Detecting Bribery } & 178\end{array}$

5.10 Sketches how Cash Generated by Illicit Activities Can Be Used to Acquire

$\begin{array}{ll}\text { Legitimate Assets } & 179\end{array}$

6.1 Standard Audit Process Model - Phase I Client Acceptance $\quad 191$

6.2 Preliminary Information Search 193 
6.3 Influences on the Client-Auditor Relationship $\quad 194$

$6.4 \quad$ Corporate Governance Structures 203

6.5 Corporate Governance Committees and Reports 204

6.6 Review of Corporate Governance Statement (UK) 209

6.7 Sample Table of Contents of New Client Proposal $\quad 219$

6.8 Sample Audit Engagement Letter $\quad 223$

$\begin{array}{lll}7.1 & \text { Audit Process Model } & 238\end{array}$

7.2a Revised ISA 315 Requires a More Robust Risk Identification and Assessment 241

7.2b Explicit Use of Automated Tools \& Techniques in the ISA 315 (Revised 2019) 242

7.3 Global Perspective of Client Risk 243

7.4 Industry, Regulatory and Other External Factors, Including the Applicable

Financial Reporting Framework Auditors Might Consider $\quad 244$

7.5 Considerations when Obtaining an Understanding of the Nature of the Entity 245

7.6 Entity Level Business Model 246

7.7 Examples of Legal Documents and Records to Consider in the Context of $\begin{array}{ll}\text { Understanding the Entity's Nature } & 247\end{array}$

7.8 Considerations Concerning Entity Objectives, Strategies and Related Business Risks $\quad 248$

7.9 Measurement and Review of the Entity's Financial Performance 249

7.10 Documentation Formats for Strategic Risk and Significant Classes of Transactions 251

7.11 How Audit Risk Works 255

7.12 Interrelationship of the Components of Audit Risk 256

7.13 Relationship between Detection Risk and Inherent/Control Risk 256

7.14 Relationship between Audit Risk and Materiality 260

8.1 The COSO Framework $\quad 285$

8.2 Understanding and Responding to IT Is an Integral Part of Understanding and Risk Analysis $\quad 290$

8.3 Components of Internal Control Framework 292

8.4 Company Organization Segregation of Duties 297

8.5 Factors on Which to Assess Internal Control Environment 300

8.6 Risk Assessment Blank Evaluation Tool 303

8.7 Typical Input, Subsystems and Output of an Information System 304

$\begin{array}{lll}8.8 & \text { Overview of Segregation of Duties } & 307\end{array}$

8.9 Overall Internal Control Evaluation Tool 312

9.1 Legal Evidence and Audit Evidence 331

9.2 Assertions Used by the Auditor 334

9.3 Audit Procedures (Evidence-Gathering Techniques) 335

9.4 Do's and Don'ts when Conducting an Audit Interview 336

9.5 Characteristics of Confirmation 341

9.6 The Attributes and Factors Used to Evaluate Information to Be Used as Audit $\begin{array}{ll}\text { Evidence } & 347\end{array}$

9.7 Factors Effecting Sufficiency and Appropriateness of Evidence $\quad 348$

9.8 Reliability of Audit Evidence 349

9.9 Linking Transactions Related Objectives, Controls and Tests of Controls for Purchases 
9.10 Test of Accounts Receivable Balance $\quad 35^{8}$

9.11 Audit Objectives and Substantive Tests $\quad 361$

9.12 Factors Influencing Sample Sizes for a Substantive Test of Details in Sample Planning

9.13 Allowable Risk of Incorrect Acceptance (TD) for Various Assessments of CR and $\mathrm{AP}$; for $\mathrm{AR}=.05$ and $\mathrm{IR}=1.0$

10.1 Important Characteristics of Analytical Procedures at Three Stages of an Audit

10.2 Four Phase Process Model, Inputs and Outputs

10.3 Five Types of Ratio Analysis

10.4 Standard Client and Industry Ratios

10.5 Indications that the Going Concern Assumption Might be Questioned

11.3 Management Representation Letter

11.4 Audit Procedures to Identify Events that May Require Adjustment of, or Disclosure in, the Financial Statements

12.2 Facebook, Exhibit 31-1 Annual Report 2018. Certification of Periodic Report under Section 302 of SOX Act of 2002

12.3 An Auditor's Report on Financial Statements Prepared in Accordance with a Fair Presentation Framework Designed to Meet the Common Financial Information Needs of a Wide Range of Users with Laws and Regulations (Derived from Auditors' Report of Leaseplan Corporation NV 2018) 
12.17 Unqualified Opinion on Both Internal Control over Financial Reporting and the Financial Statements 486

12.18 Adverse Opinion on Internal Control over Financial Reporting, Toshiba, $2017 \quad 488$

13.1 Responsibilities of the Engagement Partner $\quad 514$

13.2 Data Analytics as a Modern Technique for Traditional Audit Procedures $\quad 518$

13.3 Challenges when Using Data Analytics in the Audit. 519

13.4 Type of Work to Be Performed for Components $\quad 524$

13.5 Determining Scope for a Component Audit $\quad 525$

13.6 Information Required in Group Auditor Communication to the Component Auditor $\quad 527$

13.7 The Component Auditor Must Communicate to the Group Auditor $\quad 528$

13.8 ISA 540 (Revised) Auditing Estimates 531

13A.1 Contents of Group Audit Instructions $\quad 548$

13A.2 Subsidiaries of MaasTec and Business Structure $55^{\circ}$

13A.3 USATec and Subsidiaries REVENUE, ASSETS AND REC $55^{1}$

13A.4 Contents of Audit Planning Memorandum - Strategy Part 553

13A.5 Contents of Audit Planning Memorandum - Plan Part $\quad 55^{8}$

13A.6 Audit Program $\quad 562$

13A.7 Contents of Completion Memorandum 579

13A.8 Outline of Management Letter to MaasTe $\quad 581$

13A.9 Summary of Unadjusted Audit Differences Found in the Audit $\quad 583$

14.1 Pronouncements Issued by the IAASB, and Their Relationship to Each Other and the IESBA Code $\quad 597$

14.2 Relationships between the Five Elements of an Assurance Engagement 599

14.3 Relationships between 5 Components of Assurance Engagements 600

14.4 Components of an Assurance Report 606

14.5 Unqualified Review Report on the Financial Statements. 613

$\begin{array}{lll}14.6 & \text { ISAE } 3402 \text { Report } & 617\end{array}$

14.7 Assurance Report on Sustainability $\quad 621$

$\begin{array}{lll}14.8 & \text { Agreed-Upon Procedures } & 625\end{array}$

\begin{tabular}{ll}
14.9 & Compilation Report \\
\hline
\end{tabular} 


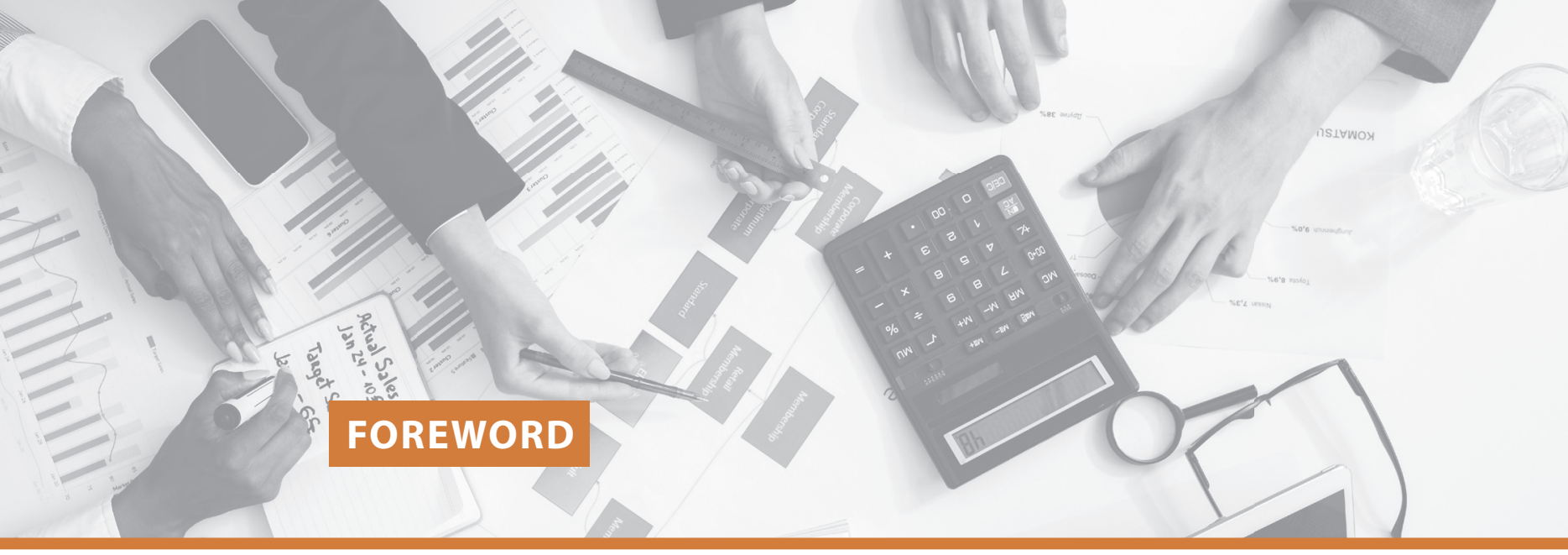

'The world has grown into a global marketplace at an exceedingly fast pace in recent years...changes in one part of the world can have significant effects on other parts.' Had I not used quotation marks, one could easily read this statement as a reference to the global financial crisis that shocked the world in 2008, or the very recent COVID-19 virus crisis. Rather, this was the observation of the then IAASB Chairman Prof. Robert Roussey, with which he started his Foreword to the first edition of this book, Principles of Auditing, in 1999. Robert continued by describing how this global marketplace had triggered the emergence of International Accounting Standards (now IFRS) and International Standards on Auditing (ISAs), and stated: 'In the late 199os, these international standards are on the brink of becoming the global standards of the future.'

Indeed, that is what they have become - and so have the 'Clarified' International Standards on Auditing. In his Foreword to the second edition_of this book in 2005, my immediate predecessor, John Kellas, started with: 'In the last few years the auditing environment has changed dramatically. The failure of Enron was perhaps the biggest single catalyst for change.... The International Auditing and Assurance Standards Board (IAASB), the independent standards-setter that operates under the auspices of the International Federation of Accountants (IFAC), has sought to respond effectively to the new environment.' Under John's leadership, the IAASB has completely rewritten the ISAs to make them more understandable and better fit for use. All 36 ISAs and International Standard on Quality Control (ISQC) 1 have clearly distinguished the auditor's objectives, the requirements of the standards, and the standards' application and other explanatory material. Many contained considerations specific to audits of smaller entities and of public sector entities, and as part of this 'clarification' effort many ISAs were also thoroughly revised for their content. This impressive exercise was essentially completed when I succeeded John as Chairman in January 2009. The full suite of these Clarified ISAs and ISQC 1 became effective for audits of financial statements for periods beginning or after 15 December 2009.

But...adoption and commitment to the use of standards is one thing. Implementation, including a thorough understanding and proper application of the standards, is another. This requires education, training, monitoring and enforcement. That is why Professors Rick Hayes, Philip Wallage en Hans Gortemaker issued the third edition of Principles of Auditing - An Introduction to International Standards on Auditing in 2014. As a co-author on the previous editions, I know how much effort that takes. But it was urgently needed, 
as I have learned time and again in my many outreach activities across the world. This indeed is a global marketplace, with dramatic and ongoing changes, and practitioners and students need to update themselves about such changes. The Clarified ISAs are one striking example, but the IAASB issues other standards as well. The third edition addressed those standards in a special chapter about other assurance and non-assurance engagements. This included revised standards on review engagements and compilation engagements, which are of particular relevance for services to smaller entities that are exempted from mandatory audits in many countries. The IAASB had also issued new assurance standards, such as International Standard on Assurance Engagements (ISAE) 3410 addressing greenhouse gas statements, a landmark standard in the area of sustainability-related assurance services engagements.

I then wrote in the Foreword: 'Will the changes stop here? A rhetorical question, of course. It is very likely that we will see expanded audit reports in the future, to better inform users of financial statements about significant audit matters. We may see the further emergence of Integrated Reporting, and assurance standards thereon. The IAASB may decide to update the ISAs for key areas such as professional skepticism, risk assessment, group audits, quality control, and may enhance the ISAs further in relation to audits of financial institutions. But that will take time, and the authors rightly decided not to wait for that.'

That is indeed what has happened, and it has resulted in a number of key revised or new standards, or exposure drafts, as well as practical guidance. A key innovation has been the revised auditor's report, including the introduction of Key Audit Matters in a new ISA 701. This has dramatically changed the contents of the auditor's report; whereas in the past it expressed only a one line conclusion (accompanied by what many saw as 'boilerplate' text), it now often contains a number of pages explaining what the auditor felt were the most significant matters in that particular audit. This makes the audit much more relevant to users of these reports such as investors, analysts and many others.

But the IAASB has also thoroughly revised fundamental standards like ISA 315 on risk assessment and ISA 540 about the audit of estimates - including explicit attention for professional scepticism, separate treatment of inherent and control risk, fraud, automated tools and techniques, and other key concepts. Furthermore, the IAASB has published exposure drafts of revised standards on quality control (now: 'quality management') and group audits, and draft guidance on 'extended external reporting' (including integrated reporting), to be finalized in 2020/21. And the ethics board IESBA has substantially revised and enhanced the Code of Ethics for Professional Accountants.

The authors of this fourth edition, Professors Rick Hayes, Philip Wallage and Peter Eimers, have revised and updated this book as far as they could, given that some revised standards are not final yet. That makes the book again highly relevant for a large variety of users all over the globe.

Have the ISAs become the 'global standards' as Chairman Roussey had anticipated in 1999? Yes, they have. The authors show in Chapter 2 that as of June 2019, 130 jurisdictions are using the ISAs. An impressive list (just think of the many translations needed!). Further, the 27 larger international networks of accounting firms have committed to using the Clarified ISAs in their global audit methodologies. The Supreme Audit Institutions (SAIs) are also using the Clarified ISAs through a special public sector version called ISSAIs. 
So, it is fair to say that there is one global language for auditing, both for the private and the public sector. And this is warmly supported by the International Organization of Securities Commissions (IOSCO), by banking and insurance regulators, and by global institutions like the World Bank, UNCTAD and IMF.

We hear, and will continue to hear, critical comments with regard to the relevance and effectiveness of audit and assurance, in light of crises and failures, as well as findings from audit inspections across the world. However, underlying these comments are the positive expectations that many have of the contributions that auditors can make to this global, dynamic marketplace, and, in turn, to financial stability and trust. That is the public interest that all of us want to serve.

I wish this book - again -a global uptake, and the readers much success with their professional endeavors.

Professor Arnold Schilder Chairman, International Auditing and Assurance Standards Board, January 2009-June 2019 


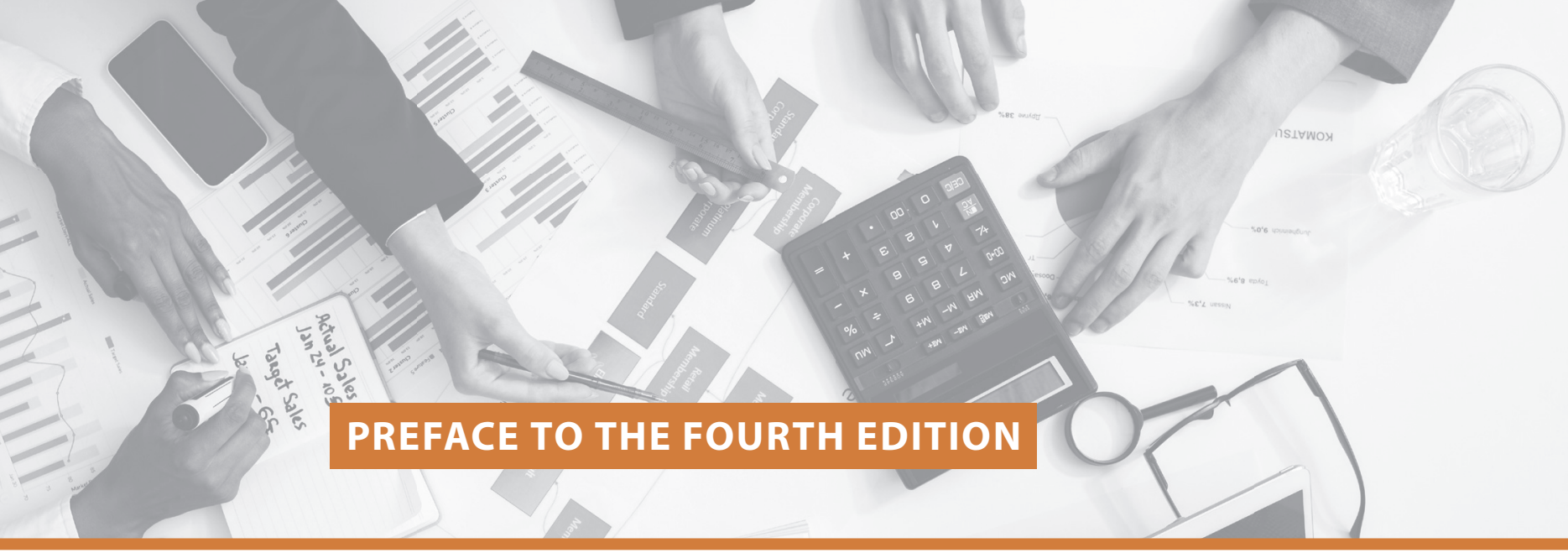

Welcome to the world of auditors by opening this book!

The audit profession has been relevant to society for several centuries. Living in a complex and dynamic world, there is a growing interest in reliable corporate reporting. Many stakeholders presume that trust is a fundament for doing business. An auditor's work is your window into the heart of an enterprise. Investors, bankers, suppliers, employees, unions, business partners in the value chain, NGOs, governments, regulators. all make use of the work and reporting by auditors.

Auditing is not like financial or managerial accounting. Accounting is a system where an objective representation of reality is recorded and summarized. Auditing is a set of procedures and techniques by which that representation is 'agreed' to specific criteria. So, accounting endeavors to record economic values, categorize them, and then summarize them in a report. Using a set of proscribed procedures (audit standards), and given specific criteria (financial accounting standards), auditing analyses whether that representation is properly recorded, categorized and reported.

You are studying auditing to further your professional goals, if you are like most people reading this book. In addition to your university or college degree you would like to get a professional credential (such as CPA, CA, RA, CFE, WP, GR, CMA, etc.), or you have heard, correctly, that auditing is a 'high demand' profession. In other words, you would like some practical knowledge which will help you in your career. To fulfil your goals is our wish.

This textbook is written from the view of the professional auditor. Theory and academic concerns are covered. The emphasis is on the professional standards promulgated by the International Auditing and Assurance Standards Board (IAASB) and the practical day-to-day experience of international auditing firms. The authors of both the current and previous editions were all extremely successful professional auditors even before writing this book. The authors are also university professors who have taught hundreds of students from around the world, so this textbook is from the point of view of the international student.

Auditing is not just about accounting issues. Auditors don't just look at (financial) data, but also at systems and processes, behavior, and how an enterprise is governed. All sorts of enterprises are audited - profit oriented, not for profit, government, private and public. Auditors may be independent of the enterprise, a valuable internal analyst or working for the government. Audit-trained accountants are also hired to do forensic 
analysis. Today, as fraudulent schemes become ever larger and more harmful, it is auditors who are an important line of defense. Auditors' detailed analytical skills have created jobs in areas as diverse as marketing and divorce consulting.

Even before we co-authors began to write the first edition of this book over 30 years ago, we all agreed that our only concern was to produce a high-quality audit text for the international student. This meant that it had to be fully up to date, use outstanding material, have a sound balance of audit theory and real practice, and be based on international auditing and assurance standards. We see the world from a truly global, cross-cultural perspective. This fourth edition is fully revised and includes the latest developments in the international Standards on Auditing, such as technology in the audit, the extended auditors report and auditing estimates.

We co-authors have a special place in our hearts for our students. We believe that it is our duty to convey our joy as auditors and audit teachers to you. 